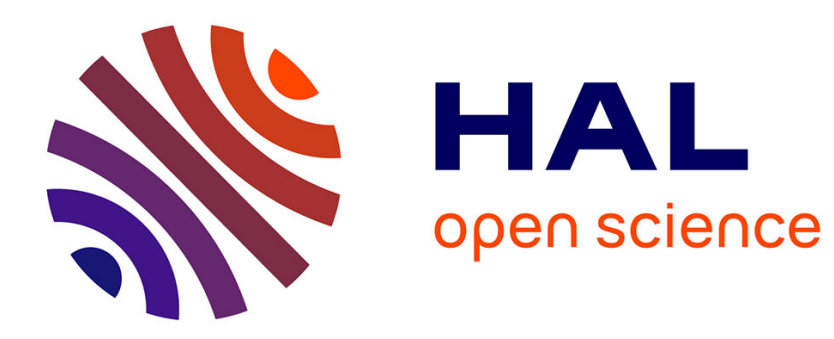

\title{
Literary Attention: The Hairy Politics of Details Yves Citton
}

\section{To cite this version:}

Yves Citton. Literary Attention: The Hairy Politics of Details . Romanic Review, 2013, 105 (1-2), pp.111-121. hal-01373164

\section{HAL Id: hal-01373164 https://hal.science/hal-01373164}

Submitted on 28 Sep 2016

HAL is a multi-disciplinary open access archive for the deposit and dissemination of scientific research documents, whether they are published or not. The documents may come from teaching and research institutions in France or abroad, or from public or private research centers.
L'archive ouverte pluridisciplinaire HAL, est destinée au dépôt et à la diffusion de documents scientifiques de niveau recherche, publiés ou non, émanant des établissements d'enseignement et de recherche français ou étrangers, des laboratoires publics ou privés. 


\author{
« Literary Attention: The Hairy Politics of Details », \\ Romanic Review, vol. 105, nbr. 1-2, May-Nov 2013, p. 111-121
}

\title{
Yves Citton
}

\section{Literary Attention: The Hairy Politics of Details}

What can literary studies bring to our experience? The fact that many scholars, on both sides of the Atlantic, have recently felt the need to address this question is usually interpreted as a symptom of a "crisis" in the literary profession. Less students, less jobs, less attractiveness, less impact, less prestige: the study of literature seems bound to follow the path taken by the study of theology during the $19^{\text {th }}$ century. Against this background feeling of gloom and doom, the steady flow of manifestoes in favor of literary studies often sounds overblown by wishful thinking. Literary interpretations, as performed in the classroom, are supposed to ground, shape and expand our moral consciousness, set the foundations for an alternative to the suicidal logics of global capitalism, and/or provide an affordable gymnastics training us to become successful among the young sharks of the creative class... Such contradictory and overambitious goals have provided an understandable backlash among more realistic, cautious or cynical colleagues.

Phil Watts never indulged in theoretical or programmatic gesturing. As a teacher, as a scholar, as a member of faculty committees, as a departmental chair, he was well aware of the challenges faced by our profession. As a reader and as a thinker, he eagerly followed the debates about the constant reconfiguration of our discipline-and his interest in Jacques Rancière and Roland Barthes bears witness to his profound engagement with literary theory, in its connection with intellectual history and political philosophy. But, to my knowledge, he never attempted directly, openly and frontally to intervene in the theoretical discussions about the evolution and the future of our profession.

This may be due to his profound humility: there is an inherent arrogance in the theoretical mode of discourse, which went against the grain of his self-effacing persona. But I believe it is also due to a deeper form of wisdom and intelligence. Phil understood that the best way to defend the study of literature was to actually perform it, rather than merely to preach it. As a teacher, as a scholar, as a family man and as a community member, he taught by example, rather than by admonition or reproach. The best thing we can do to defend, improve and expand our practice of literature is to follow his example.

We can do so by attempting to imitate him, in his kindness, generosity, caution and courage - and this is by far the best tribute we can bring to his memory: making his example as alive as possible in and through as many of us as possible. We can also try to understand what he did that was so loveable and inspiring - and this is what I will attempt to do here. Analyzing what Phil Watts did to and with literature may help us assert more powerfully the value of literary studies in our contemporary world. My thesis will be simple and 
straightforward: what Phil Watts' example teaches us is that literature, today, consists in a certain exercise and practice of attention to details.

\section{Enlarging the Scope, Narrowing the Focus}

The first question raised by my assertion is probably: attention to what? Of course, Phil Watts studied and taught literary texts: Céline, Sartre, Éluard, Camus, but also Kateb Yacine or Mohamed Dib. But his dramatically short career displays a constant and irresistible movement of expansion - from canonical metropolitan literary authors to Algerian writers, to philosophers like Rancière, and, more and more, to cinema. If Phil Watts taught and studied "French literature", then we must enlarge the scope of what we call "literature", in order to include in it not only Francophone texts, but also forgotten films, obscure film critiques, as well as aesthetical and political debates which seem to have very little to do with what was so far called "literature".

Hence the first feature in the portrait of literary studies I am proposing under the inspiration of Phil Watts' example: literary studies can no longer be defined by certain classes of objects of inquiry (isolating a pre-determined corpus), but by a certain type of attention, which can be devoted to any product of human intelligence and which I will try to define as literary attention.

Whether "reading" Céline, Camus, Kateb Yacine, Jacques Rancière, André Bazin, François Truffaut, Sergei Eisenstein or Jules Dassin, Phil Watts "literarized" his objects of inquiry by looking at them with a unique blend of curiosity, sensitivity, finesse, expectations, care and love. Because Phil was half-French, in his mind as in his genealogy and in his family, he knew that attention implies both a certain intensity of scrutiny (être attentif) and a certain offering of care (être attentionné). All of those who have been fortunate to meet him, even briefly, have experienced how attentionné Phil was as a person. His generosity and selflessness led him constantly to pay attention first to the needs and affects of others. Similarly, all of his writings bear witness to the carefulness with which he constructed historical contextualization or linguistic connotations, in order to do justice to the sentence or to the scene he was analyzing. He was as obsessively careful in his interpretations as he was selflessly caring towards the people around him.

Hence a second feature in the ideal portrait provided by Phil Watts: literary studies endeavor to teach us a certain practice of care, bearing both (and inseparably) on cultural goods and on the people that surround us. Reading a narrative, analyzing a poem, commenting a film scene: such attentional practices always involve a sensory object, to which we ought to provide our most discriminating intelligence, and other subjects, to whom we ought to give our most loving concerns. Whether in class, in an article, in a book, or sitting at a café with friends, literary interpretation constructs a reciprocally caring micro-community by refining our common sensitivity to previously unnoticed features of the cultural goods under consideration. Becoming more attentif to the object of interpretation goes hand-in-hand with becoming more attentionné towards the interpretive community.

This double movement points to a third trait in the figure of the literary scholar and teacher: at the same times as it expands the scope of what comes under consideration, literary attention consists in narrowing our common focus on apparently minor and insignificant features of the sensory or linguistic data. The example of carefulness provided by Phil Watts 
invites us to pay attention to details. To do literary work is to notice unremarkable details and to renew our perceptions and understandings of our world on the basis of these details. In order to illustrate this point, both theoretically and practically, I will now turn to a detailed analysis of a minor detail in the book Phil Watts left unfinished about Roland Barthes and Cinema.

\section{A Bald Interpretation of Hair}

Phil Watts was endowed with many natural gifts - but hair was not one of them. He often cracked jokes about his early baldness, and the obstinate recurrence of references to hair in his book on Barthes may be read within the humoristic context of such self-distancing clins d'oeil. Paying closer attention to the return of the hair-motif in the manuscript provides us with a remarkably sharp glimpse into the structure of the overall argument ${ }^{1}$.

From the first pages of the manuscript, "Barthes' approach" is explained as "a hermeneutics that takes a part (hair) for the whole and that interprets the film based on that part. But this part (hair, etc.) is also always a sensual approach to film, an aesthetic approach". As we will see, this very quote can be read as "a part" which already sketches the main articulations developed in the whole book. The hair-motif is first presented in the chapter devoted to Mythologies, rebounding on a quote drawn from "Les Romains au cinéma" (1954):

"In Mankiewicz's Julius Caesar, all the characters are wearing fringes [ont une frange de cheveux sur le front]. Some have them curly, some straggly, some tufted, some oily, all have them well combed, and the bald are not admitted, although there are plenty to be found in Roman history" (26). [...] Under Barthes's lingering gaze, Mankiewicz's film suddenly becomes a movie about hair, more precisely about "fringes." Barthes goes on to add that the "king-pin of the film" [artisan principal $d u$ film] is neither the scriptwriter nor the director but the hairdresser. The hair in Julius Caesar tells us all we need to know about the rules of verisimilitude governing Hollywood movies. It is both that which makes a Hollywood movie seem real, and the moment when the verisimilitude breaks down and "reveals a degraded spectacle, which is equally afraid of simple reality and of total artifice" ${ }^{2}$.

This chapter devoted to cinema in the Mythologies draws its title- "A Degraded Spectacle" - from this quote. It points to "Barthes' attempts to demystify the elements of the film—such as the "Roman haircut"- that participate in a film's verisimilitude, its ability to make us believe or at least suspend disbelief". Neither "simple reality" (messy hair or plain baldness) nor "total artifice", "les franges obstinées" displayed in Mankiewicz's Julius Caesar are a degraded (and degrading) spectacle insofar as they pretend to pass for real, while crushing all the diversity of details presented by reality under a flattening gloss of excess:

\footnotetext{
${ }^{1}$ A brief article sketches some of the ideas developed in the book, with a common thread already provided by the hair motif: Philip Watts, "Roland Barthes's Cold-War Cinema", SubStance 108, vol. 34, n 3, 2005, p. 17-32.

${ }^{2}$ Roland Barthes, The Eiffel Tower and Other Mythologies, Berkeley: University of California Press, 1979, p. 26-28. Apart from suggestion a possible link to Antoine Roquentin who, in La Nausée, feels disgusted by everything except looking at his own hair, Phil Watts is well aware of the fact that "contrary to Barthes' assertions, there are plenty of bald Romans in the film" (he refers to Jean-Louis Calvet on this question).
} 
Demystification of the type practiced in the 1950s, with its constant denunciation of Hollywood's artifice and excess, also participates in what we might call a left-wing asceticism. In the Mythologies, it is precisely the moments of excess that trigger Barthes's demystifying reflex. Wrestling, for instance, is "a spectacle of excess" (15), the Roman hairdo "overwhelms one with evidence" (26), Pierre Poujade's rhetoric is "tautological" (86), everything he says he says twice. What Barthes's calls "ideological abuse" (11) in the Mythologies - and which he will label doxa or power a few years later-is also a rhetorical abuse, a violation of aesthetic rules of balance, subtlety, sobriety.

This critique of "mythology", "ideology", "doxa", "power" or simply "la bêtise"which pushes Barthes pitilessly to denounce "la platitude des perruques! (here we are with hair again)" in Sacha Guitry's Si Versailles m'était conté (1953) — is only the starting point of a complex hermeneutical construction where the hair-motif will reappear as an obsessive fil rouge. Phil Watts shows that Roland Barthes' relation to cinema is much more complex than what could be concluded from a superficial reading of the texts he wrote about it. The equation Movies=Hollywood=Mythologies=US Hegemony, prevalent in Left-wing circles from the 1950s until today, can of course be observed at the horizon of Barthes' commentaries on films in the Mythologies, as well as a certain uneasiness with the massspectacle of popular cinema, contrasted to the more subtle and exclusive pleasures of reading literature. The main goal of Phil Watts' book on Barthes and Cinema is to show, however, the many other, much more positive and contrasted, layers of the complex relation Roland Barthes developed with movies through the different periods of his career.

On top of the demystifying gesture to which Barthes has long been reduced, a tantalizing hypothesis suggests a second layer linked to what Harold Beaver has named "camp poetics" in a 1981 article $^{3}$. What interests me most in the return of the hair-motif is that the negative value attached to the bourgeois vulgarity of hairstyles in Mankiewicz's Julius Cesar finds itself turned around into an aesthetic virtue of "sensuousness", "delectation" and "democratic aesthetics" - in a bold move that traces a continuous path from Barthes' film critique in the 1950s to Jacques Rancière's political aesthetics of the late 1990s:

Barthes' Marxism, the seriousness of his demystifying project, the occasional revulsion he felt at the vulgarity and the obviousness of Hollywood movies would all seem to distance him from this sensitivity that began to identify itself as camp in the 1950s. But his emphasis on style, on the sensuous surface of things, and on the outrageous detail (the Roman haircut for instance), his fascination with the excesses of rhetorical pronouncements, gangsters' gestures or an actor's makeup, his delight in the artifice of popular culture, his attraction to trashy objects (Barthes calls plastic a "magical" substance), his performance of a kind of democratic aesthetics in which anything at all can become an object of delectation, his ability to signal homosexual desire without declaring it ("l'euphorie d'Omo"), all these point to Barthes' proximity to a camp sensibility of which Hollywood was one of the main purveyors in the 1950s and 1960s.

\footnotetext{
3 “The term is from Harold Beaver's 1981 essay "Homosexual Signs (In Memory of Roland Barthes) published in Critical Inquiry 8:1, Autumn 1981 and reprinted in Camp: Queer Aesthetics and the Performing Subject ed. Fabio Cleto (Ann Arbor: University of Michigan Press, 1999)" (note by PW).
} 
The apparent disgust for the vulgarity of film as mass-entertainment is turned around into an appreciation for a sensorial experience provided by film as a medium, where "the outrageous detail" of the Roman haircut becomes a source of sensual delectation rather than of ideological contempt. Yet another return of the hair-motif will describe much more precisely and much more powerfully what is at stake in this subtle Rancierian democratic pleasure, which remains generally hidden under heavy layers of Marxist demystification.

\section{A Politics of Details}

It is in the articles Barthes devoted to Eisenstein's cinema, more specifically in "Le troisième sens" (1970), that Phil Watts retrieves this other dimension of Barthes' relation to film. And here again, it is a matter of layers: on a first level, an image displays "information"; on a second level, it conveys a "symbolic" meaning; on a third level, it carries a "sens obtus", a third meaning Barthes illustrates with photograms taken from Eiseintein's Battleship Potemkine ${ }^{4}$. And here again, references to hair-as-details happen to play a pivotal role:

Here is what Barthes sees looking at the stills of Eisenstein's films: "the compactness of the courtiers' make-up, thick and insistent for the one, smooth and distinguished for the other; the former's "stupid" nose, the latter's finely traced eyebrows, his lank blondness, his faded pale complexion, the affected flatness of his hairstyle suggestive of a wig" (53). Or later, in commenting on stills from the funeral scene in Battleship Potemkin, Barthes insists upon the "obtuse meaning" of a mourning woman's "coif, the headscarf holding in the hair [...] the closed eyes and the convex mouth" (57). [... ] This is the writing of the fetichist, the artist for whom the starting point of his commentary on cinema is always the trivial detail, the mundane. And this detail creates a distance and "de-naturalizes" (61) the story. But, this similarity aside, "The Third Meaning" rewrites and turns inside out Mythologies. For whereas Mythologies was concerned with Hollywood film, "The Third Meaning" focuses on Soviet cinema. Whereas in the 1950s Barthes situated rhetorical excess on the side of "ideological abuse," and the trickery of Hollywood, in 1970, he identifies obtuse meaning as a supplement, an "accent," and, most importantly, a fold-un pli (62). And whereas in Mythologies Barthes had used the detail to demystify Hollywood film, in "The Third Meaning" he invests the detail with affect. The courtiers' make-up, the old woman's chignon all reveal "something touching [...] or sensitive" (59), words Barthes labels "désuet"- “antiquated" (59), out of date, untimely, "with little that is revolutionary or political about them" (59). [...] It is here that Barthes makes claims, so widely imitated for a few years and then so widely disdained, about how the obtuse meaning, the detail, "outplays meaning - subverts not the content but the whole practice of meaning" (62). The obtuse meaning proposes "a new-rare-practice affirmed against the majority practice" (62). It is, Barthes concludes, a "luxury" (62), and Barthes' essay proposes an accounting for this luxury, this sensation beyond meaning. This, Barthes tells us, is the politics of art and he quotes Eisenstein: "Art begins the moment the creaking of a boot on the sound-track occurs against a different visual shot and thus gives rise to corresponding associations" (61-62). It is a question of tension internal to the image itself, removed from or in any case "indifferent" (61) to story and to character.

4 Roland Barthes, "The Third Meaning: Research Notes on Some Eisenstein Stills" in The Responsibility of Forms (Berkeley: UC Press, 1991). In Gilles Deleuze' comments on this article, Barthes appears again as a filmhater: «le cinéma il s'en fout: "J'aime pas le cinéma"; [...] ce qui l'intéresse dans le cinéma, c'est le photogramme » (Cours $d u \quad 29$ janvier 1985, disponible sur http://www2.univparis8.fr/deleuze/article.php3?id_article=299). 
This long quote summarizes the main articulation of the book on Barthes and cinema, which takes us from the common view of Barthes as a demystifier despising movies, to Barthes as an appreciator of filmic "sensation beyond meaning". But, at the same time, this quote also expresses and illustrates Phil Watts' main lesson and virtuosity on literary attention as a politics of details 5 . From "the trivial details" of hairstyle, as described in this 1970 article on Eisenstein, Phil Watts unfolds a whole "politics of art", which remarkably accounts for Barthes' four final years of teaching at the Collège de France. Let us briefly delineates three of its main articulations.

1. Literary attention appears as form of fetichism: the pleasure of the text is somewhat perversely located in overblowing the importance of a detail. It is no coincidence if a later chapter quotes another article on Eisenstein, wherein Barthes jokingly mentions that "in some cinémathèque or other a piece of film is missing from a copy of Battleship Potemkin - the scene with the baby's pram, of course - it having been cut off and stolen lovingly like a lock of hair, a glove or an item of women's underwear?" . As a summary of the chapter on Barthes and Eisenstein makes clear, the argument rests on a series of three terms, "the fetichist, the isolator, the detail": "Art, representation, Barthes claims, happens when the spectator is able to cut out a segment of the visible, to isolate and fetichize - this is Barthes' term — an object, a gesture or a scene"7.

2. While, at first sight, such fetishism, isolation and details seem to be a retreat from the political into the personal or the aesthetical, "with little that is revolutionary or political about them", they are indeed constitutive of a "politics of art", which is "affirmed against majority practice". Phil Watts' reflection on Barthes was intimately tied to his admiration for the cinema of Danièle Huillet and Jean-Marie Straub, on whom we were planning to write a book. Literary attention teaches us to become sensitive to "the creaking of a boot on the soundtrack", and invests such a sensitivity to details with a political dimension, insofar as it "outplays meaning - subverts not the content but the whole practice of meaning". A politics of art is expressed in a politics of details, carrying a "tension internal to the image itself": this is perfectly illustrated by Huillet and Straub's attention to the most minute elements of the shots they assemble in the editing room, as documented by Pedro Costa in Où gît votre sourire enfoui? (2001).

3. If the political dimension of this attitude may have eluded several generations of scholars, it is probably because it presents itself as a form of "luxury", going against the grain of a leftist spontaneous identification with the poor, the indigent, the have-nots. As fetishism seemed to retreat from the collective to the personal, the reference to luxury seemed to abandon the alignment with the proletariat and its misery, fueling Barthes' reputation as an elitist bourgeois (or culturally aristocratic) thinker. In fact, Barthes' "accounting for this luxury" locates its subversive power in "sensation beyond meaning". While this "sensation

\footnotetext{
${ }^{5}$ Naomi Schor has devoted to Roland Barthes a chapter of her book Reading in Detail. Aesthetics and the Feminine (1987), London, Routledge, 2007, p. 93-118. (I thank Evelyne Ender for providing this important reference.)

${ }^{6}$ Roland Barthes, "Diderot, Brecht, Eisenstein", p. 72.

${ }^{7}$ On these questions, Phil Watts acknowledges his debt to what he calls "one of the most convincing books on Roland Barthes", Réda Bensmaïa The Barthes Effect: The Essay as Reflective Text. Trans. Pat Fedkiew (Minneapolis: University of Minnesota Press, 1987).
} 
beyond meaning" was first denounced by the demystifier as the excess of bourgeois connotation crushing interpretation under the heavy weight of Hollywood's ideology, that same "sensation without meaning" is later perceived-via Eisenstein for Barthes, via Straub and Rancière for Phil Watts-as a luxurious reserve of aesthetic and political resistance against the sensory and semantic impoverishment imposed by mainstream media.

A quarter of a century after Barthes' death, Phil Watts re-reads him in the light of Huillet and Straub's “ecological turn”, Jacques Rancière's film critique, and Deleuzian politics. He is thus led to revisit a question which is still as suggestive today as it was in the 1970s: "How can Barthes claim that the 'luxury' that he has identified in the detail and its 'obtuse meaning' 'does not yet belong to today's politics but nevertheless already to tomorrow's'?" I will conclude with three possible directions where literary attention can connect us with a still promising politics of details.

\section{The Hairy Politics of Factishes}

The first direction points towards Jacques Rancière, whom Phil Watts contributed so actively to promote within the US academia. As we know, the "ignorant schoolmaster" staged by Joseph Jacotot must refrain from "explaining" anything to his pupils. This does not mean, however, that he should withdraw altogether from the pedagogical stage. His function remains central in classroom interaction, but mostly as a focalizer and intensifier of attention: Read this book! Look more closely at this sentence! Did you notice this choice of word? Intellectual emancipation, as modelled by Rancière musing on Jacotot's writings, puts the work of attention to details to the very core of its operations. As one of the main sites where the "deep attention" involved in close reading is practiced and nurtured in our societies, literary studies bring an important contribution to intellectual emancipation ${ }^{8}$.

The second dimension points towards Roland Barthes' insistence, during his lectures at the Collège de France, on the political necessity of caring for and about nuances ${ }^{9}$. From Mythologies to The Preparation of the Novel, Barthes ceaselessly denounced mainstream media as a crushing force bound to flatten the wealth of nuances which provide our senses and intellect with a necessary luxury of sensations beyond meaning. From the early 1950s to the late 1970s, Barthes remained committed to defending a politics of details, which merely evolved from critical demystification to sensory jubilation - as Phil Watts' detailed analysis of the few writings Barthes devoted to cinema admirably shows. Barthes" "diaphoralogy" - a neologism he created to label a "science of nuances"-intimately associated the study of literature ("codex of nuances", "master of nuances") with an ethics of the good life and a politics of resistance to mass-media homogenization. By devoting a book to Barthes and Cinema, Phil Watts reminds us that this "enlarged" conception of literature as an active culture of nuances can be found outside of the literary canon and the literary text - in films, but also, I would add, in TV series, bandes dessinées, popular songs or video games. He also reminds us, by his very method of inquiry, that the narrowing of focus on details of the object

\footnotetext{
${ }^{8}$ See on this point the remarkably balanced views expressed by Katherine Hayles in "Hyper and Deep Attention: The Generational Divide in Cognitive Modes", Profession 2007, p. 187-199 and in How We Think?, MIT Press, 2012.

${ }^{9}$ For quotes and references, see Yves Citton, « La nuance contre l'arrogance. Impressions croisées entre Roland Barthes et Gilles Deleuze », in Daniel Bougnoux (ed.), Empreintes de Roland Barthes, Paris: INA éditions, 2009, p. 147-183.
} 
under consideration makes literary attention a very powerful device, but also a luxury, a very improbable and fragile activity, condemned to hang by a hair - and, as Phil Watts knew only too well, hairs are often rare and precious.

Which bring me to the third contemporary direction of the politics of details sketched by Barthes and enacted by Phil Watts. In a section of Pandora's Hope (1999) entitled in French "Attention et prudence" ("Care and Caution" in the English version), Bruno Latour somewhat puzzlingly writes that "modernist objects were bald-aesthetically, morally, epistemologically_-but the ones produced by the nonmoderns have always been hairy,

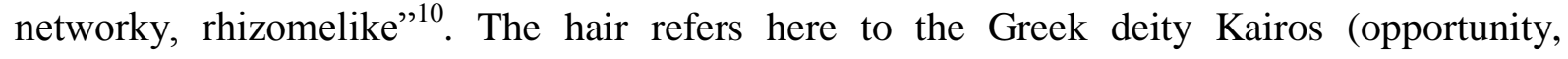
occasion), who wears hair hanging over his face, but who's back of the head is bald, so that, like a unique occasion, nobody can grasp him once he has passed by. In this chapter, Latour stages an opposition between the "facts" constructed by modern science since the $17^{\text {th }}$ century and the (pre-modern and pre-scientific) "fetishes" worshipped by supposedly "primitive" people. He does so, however, only to undermine this binary opposition: what we, moderns and nonmoderns alike, have to deal with in our daily practice and collective agency is an inseparable mix of facts and fetishes, which Latour baptizes as "factishes" (faitiches).

Factishes cannot simply be observed as mere facts: they necessarily affect us in more than merely rational ways. These affects are but the flipside of the effects we attempt to impose upon our environment. Without ever referring to Latour, Phil Watts stresses the very "factish" understanding Barthes seems to have developed of the notion of affect, identifying it with "the emotion produced by the insignificant detail" causing, in a quote drawn from Victor Burgin, "a loss of reality, a porosity to the strangeness of the world, a hallucinatory vivacity of sensations". In other words: affects manifest the fetish function still inherent to the objects we have to deal with day-in and day-out. Our practical world of hairy factishes is much more graspable than the abstract world of bald facts portrayed by the modernist scientific ideology: attention and prudence, care and caution help us catch opportunities well before we can account for their presence or their properties. But this world of hairy factishes is also a lot more messy, "échevele": bad hair days are more frequent than hair-dressed evenings.

This final digression on Bruno Latour's factishes provides us with a worthy object for literary attention, and with at least one response to our original questions. What do we do in our literary classrooms, to what goals and with what impact? Whether reading Racine, viewing Mankiewicz or Eisenstein, we train ourselves and each other to notice the hair remaining on our modern facts, as a trace of their lingering fetish-function. Our literary (or rather "litter-hairy"?) attention to details and nuances helps us identify, understand, and operate with the hairy factishes on which human agency relies, with their trail of affects, emotions, anxieties and desires.

We now understand why we cannot be attentifs to each other's gestures without being attentionnés to each other's affects - as was Phil Watts, and so generously. Like the god Kairos, Phil Watts left no hair hanging on the back of his head for us to grab and retain him among us. Our loss is enormous, but his legacy is luxuriously hairy: countless threads remain

\footnotetext{
${ }^{10}$ Bruno Latour, Pandora's Hope. Essays on the Reality of Science Studies, Cambridge MA: Harvard UP, 1999 , p. 288.
} 
to be pulled, explored and weaved in our loving memories of him, of his teaching and of his scholarly work. 